\title{
Multilingual Instructional Model of Pesantren Schools in Indonesia
}

\author{
Saidna Z. Bin-Tahir \\ English Education Department, University of Iqra Buru, Maluku, Indonesia \\ Haryanto Atmowardoyo \\ English Education Department, State University of Makassar, Makassar, Indonesia \\ Syarifuddin Dollah \\ English Education Department, State University of Makassar, Makassar, Indonesia \\ Yulini Rinantanti \\ English Teaching Program of FKIP, Cenderawasih University, Papua, Indonesia
}

\begin{abstract}
The study investigated the multilingual instructional model of pesantren schools. It employed qualitative study by applying grounded theory. This study was conducted at the three of pesantren schools in the city of Makassar, Indonesia (Pesantren IMMIM, Pondok Madinah, and Pesantren Darul Arqam Muhammadiyah Gombara). The respondent of the current study were four non-native speakers of English, Arabic, and Mandarin teachers who have the ability to speak and to communicate in three or more languages. In collecting the data, the researchers employed three primary data collection techniques, they are observation, interview, and examining the record. The results found that the multilingual instructional model of pesantren schools applied simultaneous-sequential model with some phases to generate the students changed from monolingual to multilingualism and at the end, they become mono multilingualism.
\end{abstract}

Index Terms-multilingual, instructional model, pesantren school

\section{INTRODUCTION}

The success of learning cannot be separated from the role of an instructional model of learning implemented by a teacher in teaching. The instructional model is defined as a conceptual framework that guides teachers about the stepby-step learning procedures to achieve the objectives of learning and more specific outcomes. In other words, the instructional model is a conceptual framework of the systematic teaching and learning procedures in managing the students' learning experiences to achieve the learning objectives more effectively. Thus, learning program which does not adopt a particular model will lead to unsuccessful learning and far from the objectives of learning to be achieved (Gunter, et al., 1990; Joyce \& Weil, 1980; Burden \& Byrd, 1999; Bin-Tahir, 2012).

The application of a teaching model will, of course, vary among teachers especially in teaching in a class with multilingual and multicultural students. Therefore, it is required the sufficient teacher's competence (personal, social, pedagogical, intercultural, emotional, and professional) in teaching a lesson, because it will bridge and determine the success and failure of the learning process and achievement especially in multilingual and multicultural language learning as well as in pesantren schools (Herdina \& Jessner, 2000; Ringbom, 2001; Bin-Tahir \& Rinantanti, 2016).

Most pesantren schools have multilingual teachers who are competent in teaching the multilingual subject but they faced the complicated curriculum of pesantren which adopted two or three kinds of curricula; DIKNAS (Minister of National Education) curriculum, DEPAG (Ministry of Religion Affairs) curriculum, and Pesantren curriculum (BinTahir, 2011). The three curricula were implemented separately on a certain day, different schedule, and with different teachers. Likewise in language curriculum of pesantren, the students were compelled to learn hard in fulfillment the need of those curricula. It means that the students were dazed to learn languages such as Indonesia, Arabic, English, and local languages based on the three curricula in the different schedules with the different teachers and different books. The schools also faced some obstacles in arranging the schedule and they needed more teachers to teach those languages, whereas most of their teachers have the multilingual competence to be empowered in languages teaching to fulfill the need of pesantren (Bin-Tahir, 2015a; 2015b).

Based on the results of preliminary studies in foreign languages teaching at pesantren schools shows that the success of language learning is determined by the way of the teacher choices a familiar topic and simple dialogue that is absolutely used by the students in their daily life at pesantren environment (Bin-Tahir, 2011: 34). This is supported by the consistency of pesantren policy in applying English learning in the field of science, Arabic learning in religious subjects, and Indonesian language in the field of general subjects or the social studies, while in daily interactions, they used those three languages in communication (Tahir, 2015; Amri, et al., 2017). 
The success of multilingual learning at pesantren schools is also caused by language teachers who implemented multilingual teaching through a combination of immersion, transitional, dual language, and pull out techniques; The implementation of multilingual teaching at pesantren consisted of four main specific teaching strategies; a) TeacherStudent Communication in which the teachers listen carefully to the students, and support them to use short simple sentences and nonverbal cues while speaking, and also correct the student' pronunciation; b) Student-Student Relationships in which teachers give the students opportunities to try out their new language with other students without error correction by the teacher or other students; c) Daily Routines to establish and maintain communication in the target language supported by the pesantren's rules inside or outside the classroom, and d) Language-Group Time activities in learning through the Muhaadharah (speech practicing), language camps, and meeting clubs (Bin-Tahir, 2017).

Based on this background, the researchers are interested in further studying how the successful of multilingual instructional models are applied by language teachers at that schools before further undertake a study on the development of multilingual learning materials and learning models. The results of this study will certainly contribute the information and theory for researchers themselves in developing a model of multilingual teaching and learning appropriate for pesantren schools and also give the contribution of information and references for further researchers who want to study the languages learning under the umbrella of multilingual education.

\section{REVIEW OF LITERATURE}

The instructional model is a plan or a pattern that is used as a guide to planning the learning process in the classroom. In other words, learning is a planning model or pattern which can be used to design the patterns of face-toface teaching and learning in the classroom and to determine the learning material including books, and media as a course to learn. Bin-Tahir (2012) stated that each model leads teacher in designing learning to help learners achieve the learning objectives (p.23). Joyce \& Weil (1992) stated that instructional models are models of learning to help the students acquire information, ideas, skills, values, the way of thinking and tools of expressing themselves (p.1). While Arends (2014) prefers the term of instructional model based on two important reasons; first, the term model shows a broad range of meanings rather than approaches, strategies, methods, and techniques. Any development of approaches, strategies, methods, and techniques in a systematic procedure is what is called a model. Second, the model is an important means of communication, for both the process and procedures of teaching in the classroom, presenting the material, discussing, observing, and controlling the students practicing the languages.

Multilingual is defined as the ability of a person to speak or communicate in three or more languages, either separately or in different levels of code mixing, where different languages are used actively in everyday communication within a multilingualism society (McArthur, 1992; Edwards, 1994; Vildomec, 1963; Kemp, 2009). Multilingualism is not about what several languages can do for the people but it is about what people can do with several languages (CruzFerreira, 2010). This means that there are some people who master multiple languages but they are not actively using them in daily communications so they are called mono multilingual.

Multilingual instructional models are generally adopted the models of bilingual instruction such 1) ESL program models consisted of ESL pull-out, ESL class period, and ESL resource center, 2) Bilingual program models consisted of early-exit programs, late-exit programs, two-way programs, 3) Sheltered English or content-based models, and 4) Structured immersion models. There is no reason to claim that one model is better than other models since the application of a combination of multiple models could be more effective. It depends on how to choose the level of school that the program will be implemented by considering the students' needs carefully (Collier, 1992; Ramirez, Yuen, and Ramey, 1991).

One of the most urgent issues that must be considered by stakeholders or teachers who will apply multilingual teaching is determining what language will be used as the language of instruction. For EFL/ESL learners, the Mother Tongue-Based (MTB) model is the right choice as the language of instruction and the learner's first language (L1), then the transition will be planned gradually into the second language (L2) and then into the third language (L3). The MTB learning model usually takes place exclusively in the language that the students well-known about it. In the MTB model, students have the opportunity to learn the core concepts especially in familiar language, and then they learn the vocabulary for those concepts in the new language (Malone, 2009).

Furthermore, Malone (2009) describes MTB's multilingual learning model that allows learners to establish a strong foundation on their L1 by bridging gradually to new languages (3rd language taught as the subject, but not used as instructional language) (p.71). This phase establishes students' fluency and confidence in oral L1, then teaches speaking L1 by introducing reading and writing L1, and then teaches speaking and writing L1 while introducing speaking L2, then teaching oral and written L1 and L2 orally while introducing reading and writing L2. Then teaching oral and written L1 and L2 besides introducing the oral L3, finally, teaches students' fluency and confidence in using L1, L2, and L3 for everyday communication as well as introducing reading and writing L3.

This study will focus on the Malone MLE model which adds the new languages, new content, new ideas, and new ways of thinking as a "good bridge" between language and interaction is an additive process and not a subtractive one.

\section{METHOD}


This research employed a qualitative study by applying grounded theory. The qualitative research is to collect data on the subject of research in order to obtain deep insight of the phenomena of interest. The data collected will be analyzed and interpreted descriptively or narrative (Gay, et al, 2006). Grounded theory is a systematic methodology involving the discovery of theory through the analysis of data (Strauss and Corbin, 1997).

This research was conducted at the three pesantren schools in the city of Makassar, Indonesia (pesantren IMMIM, Pondok Madinah, and Pesantren Darul Arqam Muhammadiyah Gombara). The subject of the study was four of nonnative English, Arabic, and Mandarin teachers who have the ability to speak and to communicate in three or more languages. Thus, we took four teachers as the informant (two teachers from the Pesantren IMMIM and one teacher from the respective of Pondok Madinah and pesantren Gombara). The four teachers are male. They have the ability to speak in local language, Indonesian, English, and Arabic, while the one of the pesantren IMMIM's teacher has the ability to speak in some of the local languages, Indonesian, and some of the foreign languages such English, Arabic, and Mandarin. The data gained from documentary record of their teaching activities in the classroom and data interview with them and the students.

The researchers themselves were the primary data collection instrument (Gay, et al, 2006) as an observer and an interviewer (p.425). The secondary instruments of collecting data were an observation and interview protocol.

The researchers used three primary techniques of data collection, they are:

\section{A. Observation}

Here, the researchers as nonparticipant observer or external observer in which they did not directly involve in the situation being observed. They wrote field notes in all classroom activities during the learning process. In addition, they also used a videotape to record verbal and nonverbal communication between teacher and students which later be confirmed and adjusted to field notes, and also a volunteer assisted them in the interview section.

The researchers' role as nonparticipant observer in which they did not involve directly in the teaching and learning process. They wrote field notes in all classroom activities during the learning process. In addition, they also used a videotape to record verbal and nonverbal communication between teacher and students which later be confirmed and adjusted to field notes, and also a volunteer assisted them in the interview section.

\section{B. Interview}

The researchers interviewed the teachers by using voice recorder. The kind of the interview was a semi-structured interview, it means that the researcher prepared some questions as a guide before interviewing the informant and some additional questions will be developed on the spot based on the informant answers. The teacher's interview was used to collect qualitative data or confirmation toward what had been observed, it was done at the end of every meeting. And students' interview was aimed to obtain the students' perceptions of the teacher's multilingual instructional model in languages teaching. The way to interview the students was by doing the group interview.

\section{Examining Records}

In addition to the observation and interview, the information was gathered through documentary evidence. This third primary data collection technique was examining records.

To analyze the data, the researchers employed a grounded theory technique suggested by Strauss and Corbin (1997), it consisted of three steps; open coding, axial coding, and selective coding. Open coding is a process of labeling the phenomena of multilingual instructional model implemented by the teachers in the multilingual classroom which in turn revealed the categories. Axial coding is a set of procedures whereby data on teachers' instructional model are put back together in new ways after conducting open coding by correlating those categories. Selective coding is a process of selecting from core category and connecting them with another category.

\section{RESULTS AND DisCUSSIONS}

The instructional model for languages learners in pesantren schools occupies a continuum with the multilingual model at simultaneous-sequential and Target Language-only based on the students' grade or level. Among them, there are several gradations, depending on the of students' need. The table 1 below illustrates the program phase in a multilingual learning model set for pesantren students. 
TABLE 1.

INSTRUCTIONAL MODELS FOR PESANTREN SCHOOLS

\begin{tabular}{|c|c|c|}
\hline Model and Goals & Program & Languages of instruction \\
\hline $\begin{array}{l}\text { Multilingual: Developing students' } \\
\text { literacy in Multilingual } \\
\text { (Indonesian, English, Arabic) } \\
\text { simultaneously }\end{array}$ & $\begin{array}{l}\text { - Multilingual Immersion } \\
\text { - Multilingual maintenance } \\
\text { - Multilingual pullout } \\
\text { - Developing multilingual } \\
\text { immersion }\end{array}$ & $\begin{array}{l}\text { Both foreign languages (Arabic and English) and } \\
\text { students' native language (Indonesian) used in the first } \\
\text { grade of junior high school at pesantren simultaneously }\end{array}$ \\
\hline \multirow{4}{*}{$\begin{array}{l}\text { Target Language-only: Developing } \\
\text { literacy in target language }\end{array}$} & Languages development & English and Arabic \\
\hline & Sheltered languages instruction & $\begin{array}{l}\text { Target language which adapted to the students' level } \\
\text { supporting by body language, gesture, visual and } \\
\text { movie, etc. The students' first language supporting is } \\
\text { provided in certain times. }\end{array}$ \\
\hline & $\begin{array}{l}\text { Target Languages is as second and } \\
\text { foreign language immersion }\end{array}$ & $\begin{array}{l}\text { All the instructional language provided in target } \\
\text { language based on the students' level of competence. } \\
\text { Besides, the L1 may be used separately }\end{array}$ \\
\hline & $\begin{array}{l}\text { Target Languages as second and } \\
\text { foreign languages pullout }\end{array}$ & $\begin{array}{l}\text { Target language; Students are taught in the main } \\
\text { classes with ESL instructional support. }\end{array}$ \\
\hline
\end{tabular}

The multilingual instructional model of pesantren schools implemented the MTB model in the teaching and learning foreign languages namely English and Arabic. The program varies in students' intensity and duration to join this class. This multilingual model developed student skills in three languages simultaneously in the first phase. They provide Indonesian, English and Arabic lessons with equal proportions that aim to strengthen the students' mother tongue and to encourage the development of their second and third languages. This model impacted to an additive multilingual environment in which all students are expected to develop their multilingual capabilities. (Teachers present some academic content in three languages (Indonesian, English, and Arabic) simultaneously so students are interested and eager to develop their language skills). It can be seen in extract 1 below:

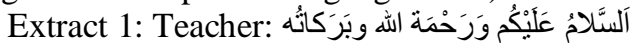

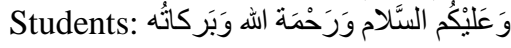

Teacher: Selamat pagi anak-anak

Students: Selamat pagi, Pak

Teacher: Good morning students

Students: Good morning, Sir

Teacher: كَيْنَ حَالُكُمُ اليَوْج

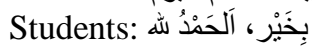

Teacher: Bagaimana kabar kalian hari ini?

Students: Baik, alhamdulillah

Teacher: How are you today?

Students: We are fine

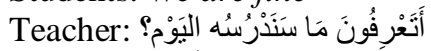

Students: لا، يَا أسنتَّاذم

Teacher: Tahukah kalian apa yang akan kita pelajari hari ini?

Students: Tidak, Pak

Teacher: Do you know what will we learn today?

Students: No, Sir

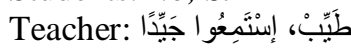

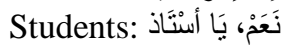

Teacher: Baik, dengarkan baik-baik

Students: Iya, Pak

Teacher: Well, listen carefully!

Students: Yes, Sir

The extract 1 shows that the multilingual instructional model applied by teachers was using simultaneously exposing the various languages instruction or by translating the target language (TL) into the students' L1 concurrently. This is meant to increase both the students' interest and motivation to master those languages and to make them familiar and confident in using those languages in their daily communication. This multilingual instructional model has offered many languages to be mastered at the beginning of learning (e.g. Indonesian, English, Arabic, and local languages), and it can help students to maintain their native language and cultural background while developing their academic and linguistic skills in English and Arabic by enriching their vocabulary and expressions.

In the second phase of multilingual instruction in pesantren was Target Language (TL)-only model. This model describes the programs that offer the language teaching to the learners in their target language. Their mother tongue 
does not play a significant role in the target language-only program, although multilingual teachers and instructors may provide some supports, such as providing instruction in their mother tongue to assist them acquiring the language skills. This model aims to focus on one target language or as a stabilization process of acquiring target languages.

The last stage of multilingual teaching in pesantren was a bilingual transition program. Students can receive second language instruction only in two languages (early-exit) or (late-exit) along with third language teaching. The proportion of language usage may vary from 50-50 (students get 50\% of teaching in English and 50\% in Arabic without their mother tongue) to 60-40 or 70-30 portions, depending on the pesantren or school policy. The Early-Exit program differs from Late-Exit in focusing more on directing the learners' target language to TL-only quickly and less in maintaining students' native language proficiency.

It is so easy to transition students from the bilingual teaching to the mainstream of TL classroom depending on their skill level in English and Arabic. The language learners of pesantren often show the declining of their academic achievement during the transition year. Without the support they get during the transition period, TL learners may need continued assistance in their native language and further support in the development of the TL of their first class. For example, students may have sufficient English language proficiency, but their academic English is insufficient to complete the tasks related to the content of knowledge without support. The high school students may find the transition to teaching English particularly difficult because of the high school academic content becomes more difficult. Students need knowledge of literacy and sufficient of English knowledge in making the meaning from their textbooks and classroom experiences.

In multilingual instruction models of pesantren above, when compared to the multilingual instructional model proposed by Malone (2005), it will be found the opposite of the Malone's model, where the initial instruction given to new students by using the simultaneous multilingual instruction for the purpose of enriching vocabulary and phrase mastery by students. The next phase is stabilization on each target language that will eventually focus on foreign language, namely English and Arabic. It can be seen in figure 1 below:

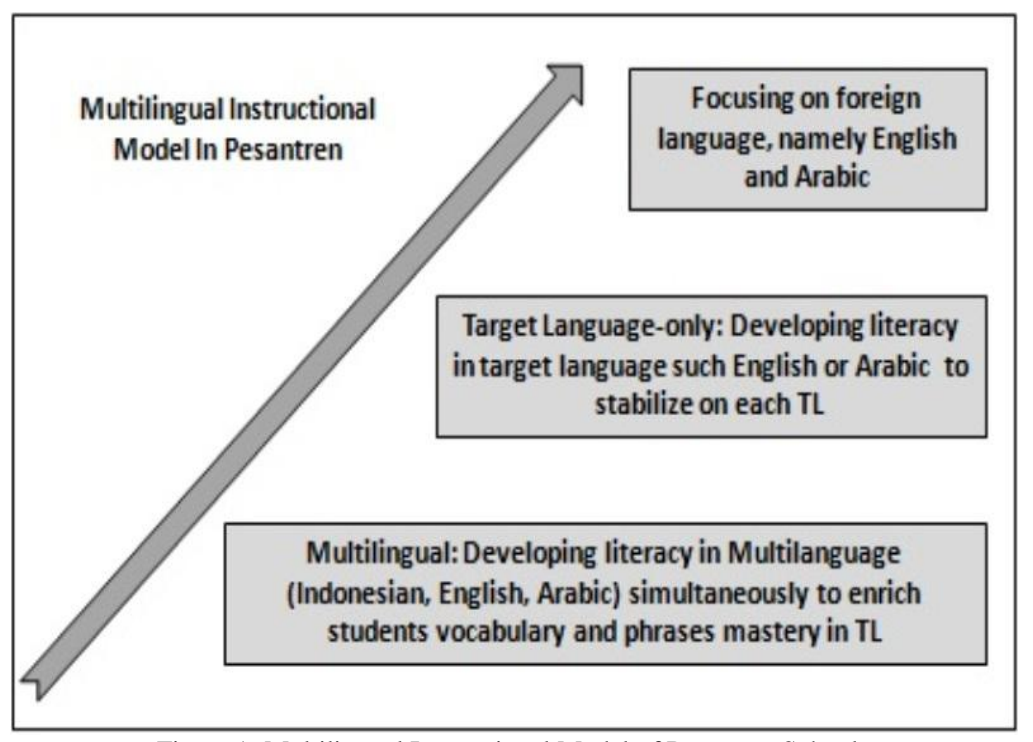

Figure 1: Multilingual Instructional Model of Pesantren Schools

The Figure 1 shows that the multilingual instructional model of pesantren schools applied simultaneous-sequential model with some phases to create students from monolingual become multilingualism and then be a mono multilingualism. It began by building the students' fluency and confidence in using L1, L2, and L3 orally for everyday communication, continue building oral L1, L2, and L3 by introducing reading and writing L2, and L3, continue building oral and written L2 and L3 specifically and separately, continue building reading, written, and oral L2 and L3, continue building fluency and confidence in using L2 and L3 in monolingual classroom.

This multilingual instructional model in pesantren schools was only based on the observation of languages teaching and learning activities which cannot be generalized and it still needs some further studies to develop and measure the effectiveness of its implementation.

\section{CONCLUSION}

Based on the results and discussion, the researchers concluded that the multilingual instructional model of pesantren schools applied simultaneous-sequential model with some phases to induce the students changed from monolingual into multilingualism and at the end, they become mono multilingualism. It begun through some phases i.e. building the students' fluency and confidence in using L1, L2, and L3 orally for everyday communication, then teaching speaking L2, and L3 by introducing reading and writing L2, and L3, then building speaking and written L2 and L3 specifically 
and separately, continue teaching reading, written and speaking L2 and L3, then building the students' fluency and confidence in using L2 and L3 in monolingual classroom based on the field of the subject.

The results of the qualitative analysis cannot be generalized to the other schools and situations. Thus, the researchers suggested measuring the effectiveness of this study quantitatively to reinforce the results that will be proposed by the researchers themselves in conducting need and situational analysis before applying research and development (R\&D).

\section{ACKNOWLEDGMENTS}

The research was financed by The Directorate General of Resources for Science, Technology and Higher Education of Indonesia. Thanks also to John Evar Strid, Ph.D and Professor Trude Jackobson, Ph.D at Northern Illinois University, USA for their contribution and supervision in finishing this article.

\section{REFERENCES}

[1] Amri, M., Tahir, S. Z. A. B., \& Ahmad, S. (2017). The Implementation of Islamic Teaching in Multiculturalism Society: A Case Study at Pesantren Schools in Indonesia. Asian Social Science, 13(6), 125. Doi: https://doi.org/10.5539/ass.v13n6p125.

[2] Arends, R. (2014). Learning to teach. McGraw-Hill Higher Education.

[3] Bin Tahir, S. Z. (2011). The Effectiveness of English teaching method at Pesantren IMMIM of Makassar. JUPITER Journal UPT Library of University of Hasanuddin, 9(1), p.81-87.

[4] Bin Tahir, S. Z. (2012). Teaching English as World Language: Pengajaran Bahasa Inggris. Jakarta: Media Pustaka Qalam.

[5] Bin Tahir, S. Z. (2015a). The attitude of Santri and Ustadz toward multilingual education at Pesantren. International Journal of Language and Linguistics, 3(4), 210-216. Doi: 10.11648/j.ij1l.20150304.13.

[6] Bin Tahir, S. Z. (2015b). Multilingual Education in Pesantren Context. Yogyakarta: Deepublish.

[7] Bin-Tahir, S. Z., \& Rinantanti, Y. (2016). Multilingual Lecturers' Competence in English Teaching at the University of Iqra Buru, Indonesia. Asian EFL Journal, Indonesian International Conference Edition, 5, 79-92.

[8] Bin Tahir, S. Z. (2017). Multilingual teaching and learning at Pesantren Schools in Indonesia. Asian EFL Journal, 89, 74-94.

[9] Burden, P. R., \& Byrd, D. M. (1996). Method for effective teaching, second edition. Boston: Allyn and Bacon.

[10] Cruz-Ferreira, M. (2010). Multilinguals are...? London: Battlebridge Publications.

[11] Collier, V. P. (1992). A Synthesis of studies examining long-term language minority student data on academic achievement. Bilingual Research Journal, 16. 187-212.

[12] Edwards, J. (1994). Multilingualism. London: Routledge.

[13] Gay, L. R, Mills, G, and Airasian, P. (2006). Educational Research; Competencies for Analysis and Applications. Eight Edition. New Jersey; Pearson Prentice Hall.

[14] Gunter, M. A., Estes, T. H., \& Schwab, J. H. (1990). Instruction: A models approach. Boston: Allyn and Bacon.

[15] Herdina, Phillip; Jessner, Ulrike. (2000). The dynamics of third language acquisition". In: Cenoz, Jasone; Jessner, Ulrike (eds.) English in Europe. The Acquisition of a Third Language. Clevedon: Multilingual Matters. 84-98.

[16] Joyce, B., \& Weil, M. (1980). Model of teaching. New Jersey: Prentice-Hall, Inc.

[17] Joyce, B., \& Weil, M., (1992). Models of teaching. Fourth Edition. Englewood Cliffs, NJ: Prentice-Hall.

[18] Kemp, C. (2009). Defining multilingualism. In L. Aronin \& B. Hufeisen (Eds.), The exploration of multilingualism. Amsterdam, The Netherlands: John Benjamins. 11-26.

[19] Malone, S. (2005). Education for Multilingualism and Multi-literacy in Ethnic Minority Communities: the situation in Asia. In First Language First: Community-based literacy programmes for minority language context in Asia. Bangkok: UNESCO, pp.71-86.

[20] McArthur, T. (ed). (1992). The Oxford Companion to the English Language. Oxford: OUP.

[21] Ramirez, J. D., Yuen, S. D., \& Ramey, D. R. (1991). Longitudinal study of structured English immersion strategy, early-exit, and late-exit transitional bilingual education programs for language-minority children. San Mateo, CA: Aguirre International.

[22] Ringbom, Håkan. (2001). Lexical transfer in L3 production. In: Cenoz, Jason; Hufeisen, Britta; Jessner, Ulrike (eds.). Crosslinguistic Influence in Third Language Acquisition: Psychological Perspectives. Clevedon: Multilingual Matters; 59-68.

[23] Strauss, A., \& Corbin, J. M. (1997). Grounded theory in practice. California, US: Sage Publications.

[24] Tahir, B., \& Zulfiqar, S. (2015). Multilingual Behavior of Pesantren IMMIM Students in Makassar. Asian EFL Journal, 86, 4564.

[25] Vildomec, V. 1(963). Multilingualism. Leyden: A.W. Sythoff.

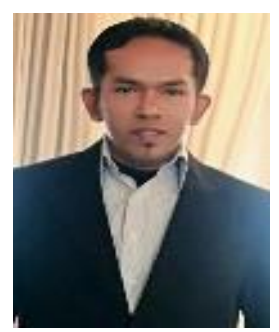

Saidna Z. Bin-Tahir was born in Ambon, Indonesia on June $11^{\text {th }}$, 1974 . He is currently a doctoral candidate in English Education Department at the State University of Makassar. Indonesia. He graduated his BA from Al-Azhar University of Cairo in Arabic Language and Linguistics in 2006 and graduated his master degree in English Education Department of the State University of Makassar in 2012.

He is a lecturer at English Education Department of the University of Iqra Buru, Maluku, Indonesia. He has published some books for the last of three years including 1) Teaching English a World Language: Pengajaran Bahasa Inggris. Jakarta: Media Pustaka Qalam, 2013; 2) Multilingual Education in Pesantren Context, Yogyakarta: Deepublish, 2015. He also has published many articles in TEFL, ICT in language learning, and Multilingual teaching and learning such 1) The Attitude of Santri and Ustadz toward Multilingual Education at Pesantren, International Journal of language and Linguistics, Vol. 3(4), 2015; 2) Multilingual Behavior of Pesantren IMMIM Students in Makassar, Asian EFL Journal, Vol. 86, 2015; 3) Multilingual Lecturers' Competence in English Teaching at the University of Iqra Buru, Indonesia. Asian EFL Journal, 5, 2016; and 4) Multilingual Teaching and Learning at Pesantren Schools in 
Indonesia, Asian EFL Journal, Vol. 98, 2017. Mr. Bin-Tahir had become a member of Asia TEFL, reviewer and editor in some local and international journals, and a head of the language center at the University of Iqra Buru, Indonesia.

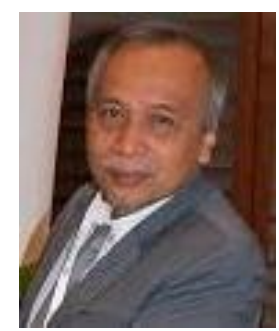

Haryanto Atmowardoyo was born in Purbalingga, Central Java, Indonesia on October 29, 1959. He is a professor of English Education at English Department of State University of Makassar, Indonesia. He completed his Elementary education in SD Galuh, Purbalingga in 1971, Junior High School at SMP Borroneus Purbalingga in 1974, and Senior High School at SMA Negeri Purbalingga in 1977. He completed his bachelor degree in 1977 and Master Degree in English education at IKIP Malang. He obtained his doctoral degree in English Education at IKIP Jakarta in 1999.

He participated in academic Recharging Program in OHIO State University, Columbus, OHIO, USA from September 2009 to January 2010. He has published several books : Isu Pendidikan dan Pengajaran Bahasa (2001), published by State University of Makassar Press; Dasar-Dasar Penulisan Proposal Penelitian (2008), a collaborative work with Sukandarrumidi, of Gajah Mada University, published by Gajah Mada Press (2008); and Metodology Penelitian Kualitatif; Teori Dasar (2008) published by State University of Makassar press. Some articles have also been published either in newspaper, in on line journal, or in printed scientific journals; Cara Mudah Belajar Bahasa Inggris, Lokalisasi Pengajaran Bahasa Inggris; Fisibilitas Lokalisasi Pengajaran bahasa Inggris; and perlukah Revolusi Pengajaran Bahasa Inggris published in Fajar and Pedoman Rakyat in 1994; Critical analysis on teacher's Made Test (performance, 1995); Laboratorium bahasa multilmedia dan Fungsinya dalam Pembelajaran Bahasa Asing (20050, Pendidikan Network).

Prof. Atmowardoyo has presented some papers in international conferences: Research Methods in TEFL; Grammatical Error in Indonesian EFL Learners' Writing (May 2007, Jakarta, Annual Linguistic Conferences of Atmajay University); A Lesson for Intenational Journal (Hanoi, Vietnam, August 2010, the 8 the Asia TEFL Conference), Qualitative research in TEFL Studies ( Makassar, 2 nd ICOLE Conference, December 2010) and Learners' Perception on the Personal and Professional Competences of Effective and Ineffective EFL Teachers $\left(21^{\text {st }}\right.$ Century Academic Forum Conference, Harvard, University, Boston US in 2016

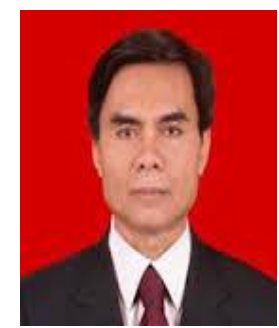

Syarifuddin Dollah was born in Bua-Bua, Pinrang, Indonesia on December 31, 1963. He is currently a lecturer of English Education Department of the State University of Makassar. He graduated his S1 and S2 from IKIP Ujung Pandang in 1996 and graduated his doctoral program from Hasanuddin University, Makassar, Indonesia in 2006.

He has published many articles in his field of study including 1) The Effect of Self-esteem, Anxiety, and Gender on Oral Communication of EFL Students of Universitas Negeri Makassar (2006); 2) Pengembangan Model dan Perangkat Pembelajaran Bahasa Inggris Berbasis Islami dengan Pendekatan "Content-Based Instruction” Siswa Madrasah Tsanawiyah (MTs) di Sulawesi Selatan (Unggulan Perguruan Tinggi) (2016). He also attanded and presented many international conferences abroad.

Dr. Dollah is more active in many professional organizations such 1) member of Masyarakat Linguistik Indonesia (MLI) Cabang UNM; 2) Member of Asia TEFL; 3) Member of TEFLIN, and 4) Manager of ADRI SULSEL. Now he is a dean of language and literature faculty of the State University of Makassar, Indonesia.

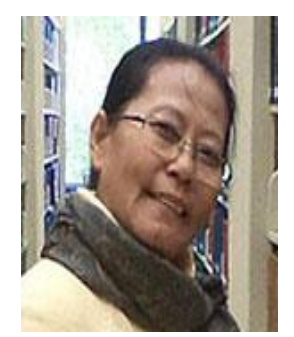

Yulini Rinantanti was born in Kediri East Java, Indonesia on July 22, 1963. She is currently a doctoral student at English Education Department of State University of Makassar, Indonesia. She completed her bachelor degree in English teacher education from Cenderawasih University in jayapura, Papua-Indonesia in 1988 and her master degree in tefl from James Cook University in Townsville, Queensland-Australia in 2001.

She is a lecturer at English Teaching Program of Faculty of Teacher Training and Education, Cenderawasih University-Papua, Indonesia. She has been a presenter in both national and international conference on EFL teaching and learning. The last three articles she has written were: 1) Attitude toward Autonomy in in Learning English: A Case in Cenderawasih University Papua, Indonesia, Asian EFL Journal/ Professional Teaching Articles. August $(86), 2015 ; 2$ ) Multilingual Lecturers' Competence in English Teaching at the University of Iqra Buru, Indonesia. Asian EFL Journal, 5, 2016; and 3) Mapping of the Competence of SHS Students in English Subject in Sarmi and Mamberamo Raya Regencies Papua, Indonesia. The Asian EFL Journal. TESOL Indonesia International Conference Edition, Vol.10, 2016. Her research interests are in the area of Teaching English as a Foreign Language and a Second Language and EFL Teachers' Professionalism.

Ms. Rinantanti is a secretary of Teachers Certification Program area 131 Papua and West Papua provinces, Indonesia, a member of Indonesian Education Scholars Association (ISPI), and an editor of Jurnal Ilmiah Kependidikan FKIP UNCEN Jayapura. 